\title{
Interhospital transfer of COVID-19 patients treated with high-flow nasal oxygen therapy
}

\author{
Elophe Dubie $^{1 *}$ D, François Morin², Dominique Savary ${ }^{2,3}$, Amaury Serruys $^{1}$ and Pascal Usseglio
}

\begin{abstract}
At the start of the COVID-19 pandemic, early intubation was recommended on the basis of worldwide observations of severe hypoxemia. However, some patients were ultimately able to benefit from high-flow nasal cannula (HFNC) and thus avoid intubation. During the "second wave" (September to December 2020 in France), some emergency departments implemented HFNC in patients with severe COVID-19. The question then arose regarding the transfer of these most serious patients to intensive care units (ICU) and of the respiratory modalities to be used during this transfer. To assess the feasibility of interhospital transfers of COVID-19 patients needing HFNC, we conducted a bicentric prospective observational study of all medical transfers of patients needing HFNC with the Chamberry and Angers (France) mobile emergency and intensive care service (SMUR) during the "second wave" of the COVID-19 pandemic in France. Analysis of these 42 patients showed no significant variation in the respiratory requirements during the transfer. Overall, 52\% of patients were intubated during their stay in ICU, including three patients intubated before or during transfer. Interhospital transfer with HFNC is very high-risk, and intubation remains indicated in the most unstable patients. However, $48 \%$ of patients benefited from HFNC and were thus able to avoid intubation during their transfer and ICU stay; for these patients, intubation would probably have been indicated in the absence of available HFNC techniques.
\end{abstract}

Keywords: COVID-19, Interhospital, Transfer, High-flow, Nasal, Oxygen

\section{Introduction}

At the start of the COVID-19 pandemic, early intubation was recommended on the basis of worldwide observations of severe hypoxemia. However, some patients were ultimately able to benefit from high-flow nasal cannula (HFNC) [1]. Before the COVID-19 pandemic, high-flow nasal cannula (HFNC) had been a major advance in the treatment of patients with hypoxemic lung disease, enabling them to avoid intubation and its potential complications [2, 3]. HFNC is now recommended by the French Society of Emergency Medicine in "deeply hypoxemic"

\footnotetext{
* Correspondence: elophe.dubie@ch-metropole-savoie.fr

${ }^{1}$ Emergency Department, Metropole Savoie Hospital, BP 1125, 73000 Chambery, France

Full list of author information is available at the end of the article
}

COVID-19 patients to limit the use of invasive mechanical ventilation [4]. During the French "COVID-19 second wave" (September to December 2020), some emergency departments implemented HFNC in clinically severe COVID-19 patients. For some of these patients, HFNC was the only alternative to intubation, as conventional oxygen therapy was not sufficient. The question then arose regarding the transfer of these most serious patients to intensive care units (ICU) and of the respiratory modalities to be used during this transfer. To our knowledge, there are few descriptions in the literature of medical transfer of adult patients needing HFNC [5]. We aim to assess the feasibility of interhospital transfers of COVID-19 patients needing HFNC.

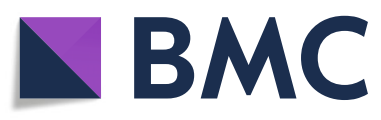

(c) The Author(s). 2021 Open Access This article is licensed under a Creative Commons Attribution 4.0 International License, which permits use, sharing, adaptation, distribution and reproduction in any medium or format, as long as you give appropriate credit to the original author(s) and the source, provide a link to the Creative Commons licence, and indicate if changes were made. The images or other third party material in this article are included in the article's Creative Commons licence, unless indicated otherwise in a credit line to the material. If material is not included in the article's Creative Commons licence and your intended use is not permitted by statutory regulation or exceeds the permitted use, you will need to obtain permission directly from the copyright holder. To view a copy of this licence, visit http://creativecommons.org/licenses/by/4.0/. The Creative Commons Public Domain Dedication waiver (http://creativecommons.org/publicdomain/zero/1.0/) applies to the data made available in this article, unless otherwise stated in a credit line to the data. 


\section{Materials and methods}

To assess the feasibility of interhospital transfers of COVID-19 patients needing HFNC, we compared the respiratory requirements at the start and at the end of the transfer. We conducted a bi-centric prospective observational study of all medical transfers of patients needing HFNC with the Chambéry and Angers (France) mobile emergency and intensive care service (SMUR) during the French "COVID-19 second wave". The inclusion criterion was COVID-19 patients needing HFNC and requiring a medical interhospital transfer to an intensive care unit. The exclusion criterion was intubation or use of another mode of oxygenation than HFNC before the arrival of the medical team responsible for the transfer. We are describing here only interhospital transfers and not primary management at home by a medical team. Heater humidifiers (MR850, Fisher \& Paykel) coupled to a turbine ventilator (Monnal T60, Air Liquide Medical Systems) were installed in our ambulances. The oxygen reserves in the ambulances were increased to $30 \mathrm{~L}$ of oxygen at 200 bars. The COVID + status of the patients was known before the treatment was started. The indication of HFNC was possible in the event of persistent polypnea and hypoxemia (based on a subjective assessment) despite conventional oxygen therapy and in the absence of immediate or foreseeable short-term intubation criteria. Biological measurement of hypoxemia was not systematic. The intubation criteria were hypercapnia $\left(\mathrm{PaCO}_{2}>45 \mathrm{mmHg}\right.$ on arterial blood gas), hemodynamic instability, respiratory exhaustion, and impairment of consciousness. Initially, the flow rate was set at $50 \mathrm{~L} / \mathrm{min}$. $\mathrm{FiO}_{2}$ was started at $100 \%$ and adjusted down to $\mathrm{SaO}_{2}$ target (92-96\%). The initial temperature was $37^{\circ} \mathrm{C}$ and adjusted down to $34{ }^{\circ} \mathrm{C}$ if needed for better tolerance. HFNC equipment was set up at the patient's bed. Airborne and contact protections recommended by our hospitals (respirator N95 or FFP2, gown, gloves, eye protection) were applied, as well as the renewal of the air in the ambulance by extractor (theoretical maximum flow of $700 \mathrm{~m}^{3} / \mathrm{h}$ ). A droplet mask was placed over the patient's nose and nasal interface, if tolerated. The number of health care professionals in contact with the patient in the ambulance had to be kept to a strict minimum. Monitoring was particularly close during different phases of transport, especially using the Rox score [6] as not to delay an intubation, for example, if the HFNC failed to maintain adequate oxygenation. Ventilation parameters $\left(\mathrm{FiO}_{2}\right.$ and flow rate) and respiratory requirements (respiratory rate, oxygen saturation) were collected on departure and on arrival, on the patient's medical file, and then reported in an Excel spreadsheet. We analyzed the patients' outcomes of intubation and one month survival. The study was conducted according to the reference methodology MR004 and registered in the directory of the National Institute of Health Data.

\section{Results}

Forty-two patients were included from September 2 to December 9, 2020. The median (interquartile) age of the patients was $72(65-78)$ years. A total of $69 \%$ were male. Fifty-two percent of the patients were treated for hypertension. One patient had to be intubated by the medical team in charge of the transfer before the transfer and thus was excluded from the analysis. This was the only patient excluded from the analysis. Two patients had to be intubated during the transfer by Angers SMUR. For these two patients, the respiratory rate (RR) and oxygen saturation $\left(\mathrm{SaO}_{2}\right)$ values before intubation were entered as "final" respiratory requirements. The overall analysis of patients showed no significant variation in the respiratory requirements of the patients during the transfer (Fig. 1). At the beginning of the transfer, the $R R$ and $\mathrm{SaO}_{2}$ medians were 30/min (26-32) and 92\% (90-95), respectively. At intensive care unit admission, the RR and $\mathrm{SaO}_{2}$ were measured at 28/min (22-32) and 93\% (90-95), respectively. Ventilation settings were not changed significantly during the transfer period: At the beginning of the transfer, the flow and $\mathrm{FiO}_{2}$ medians were $50 \mathrm{~L} / \mathrm{min}$ (50-60) and 75\% (53-100), respectively. At intensive care unit admission, debit and $\mathrm{FiO}_{2}$ were $50 \mathrm{~L} /$ min (50-60) and 80\% (50-100), respectively. Overall, $52 \%$ of patients were intubated during their stay in the ICU, including three patients intubated before or during transfer. The median Rox score at the start of the transfer was 3.3 in patients intubated and 6.8 in nonintubated patients, after exclusion of one patient with a treatment limitation decision. No patient had to be urgently intubated upon arrival in the ICU. Survival at 1 month after admission to the ICU was $74 \%$.

\section{Discussion}

There are very few descriptions in the literature of medical transfer of adult COVID-19 patients needing HFNC, so our study population cannot be compared to most studies. The respiratory requirements of the patients corresponded to the indications for HFNC. However, the respiratory status of some patients was particularly severe. This may explain the high proportion of intubated patients during their ICU stay. For these patients, other causes of decompensation could have compounded the patients' respiratory efforts, such as pulmonary embolism, heart failure, and superinfection. But in our cohort, ICU follow-up ruled out these causes of initial decompensation. When HFNC is started, the objectives are a decrease in the respiratory rate and an increase in oxygen saturation. Then, during mobilizations and ambulance transport, the objective is to maintain 

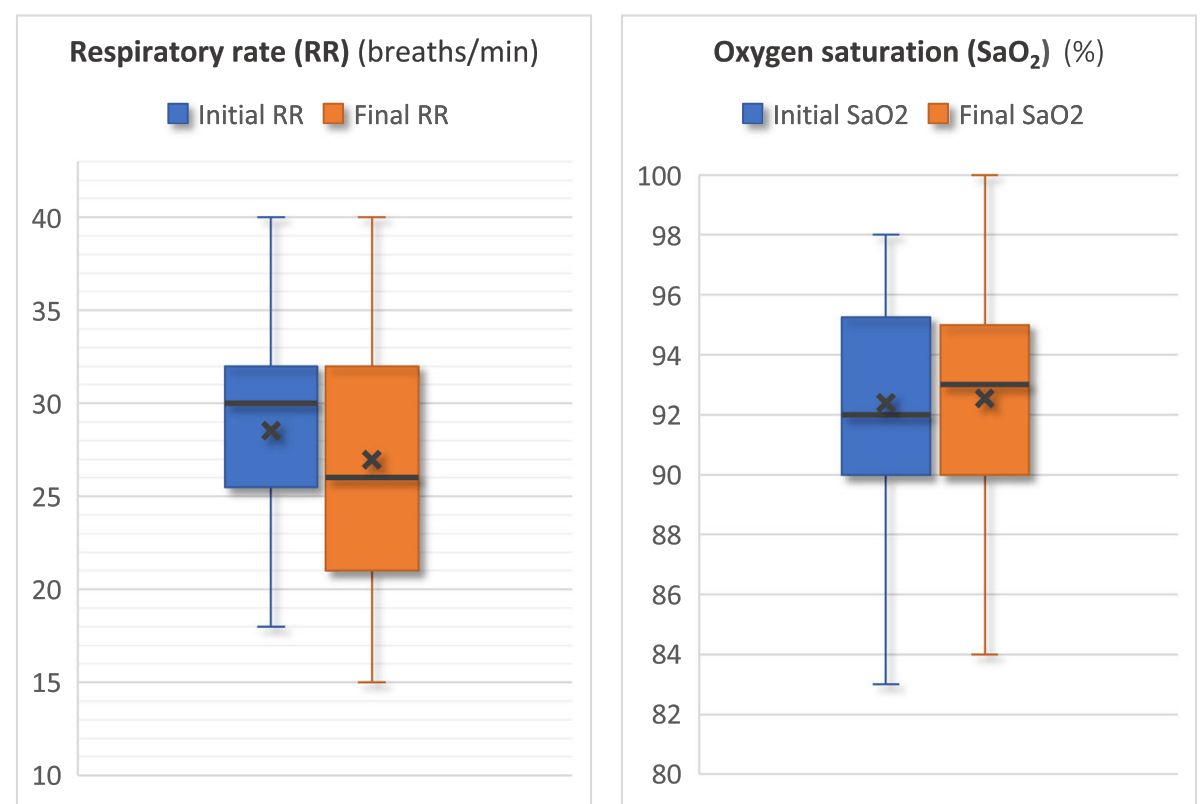

Fig. 1 Respiratory rate and $\mathrm{SaO}_{2}$ at the start and end of the transfer. The horizontal line represents the median, and the $x$ represents the mean. The vertical limits of the box represent the first and third quartiles. The extremities represent the maximum and minimum values

the stability of these respiratory requirements. Between the patient's room and the intensive care ambulance, during which the power supply to the heater humidifier is interrupted, humidification and heating of the airoxygen mixture are no longer guaranteed. Did this lack of warming and humidification contribute to the sudden deterioration of the respiratory state of the two patients who were intubated? This led us to recommend that the need for a prolonged interruption of power supply would contraindicate a transfer with HFNC, unless the transfer is after a prior weaning trial. Interhospital transfer with HFNC is very high-risk, and intubation remains indicated in the most unstable patients.

However, $48 \%$ of patients benefited from HFNC and were thus able to avoid intubation during their transfer and ICU stay; for these patients, intubation would probably have been indicated in the absence of available HFNC techniques. Ideally, we would have liked to compare the survival of two cohorts of patients. Are these patients (who are transferred on HFNC) having overall better survival rates or approximately the same as their intubated cohorts? The main obstacle to using HFNC in COVID-19 patients was the fear of an increased risk of contamination for personnel due to the aerosolization produced when using HFNC. However, a few trials did not appear to show that there is an increased risk of contamination with HFNC compared with other modes of oxygenation, including high concentration masks [7-9]. Our small trial needs to be expanded to a larger patient population for more concrete evidence of HFNC benefits in interhospital transfers. Finally, alternatives to HFNC are possible, such as non-invasive ventilation or continuous positive airway pressure.

\section{Conclusions}

This study shows the feasibility of interhospital transfers of COVID-19 patients needing HFNC. No significant variation in the respiratory requirements of the patients was observed during the transfer. However, these transfers with HFNC are very high-risk.

\section{Acknowledgements}

We would like to thank the clinical research unit of the Metropole Savoie Hospital.

Authors' contributions

All authors concurred with the submission of this manuscript; they have reviewed and approved its final version.

\section{Funding}

Dominique Savary benefited from accommodation and catering costs being covered by the Fisher \& Paykel and Air Liquide Medical Systems. Nothing was declared by the remaining authors.

\section{Availability of data and materials}

The datasets analyzed during the current study are available from the corresponding author on reasonable request.

\section{Declarations}

Ethics approval and consent to participate

The study was conducted according to reference methodology MR004 and registered in the directory of the French National Institute of Health Data.

Competing interests

The authors declare that they have no competing interests. 


\section{Author details}

${ }^{1}$ Emergency Department, Metropole Savoie Hospital, BP 1125, 73000

Chambery, France. ${ }^{2}$ Emergency Department, Angers University Hospital, Angers, France. ${ }^{3}$ IRSET (Research Institute for Environmental and

Occupational Health) - UMR_S 1085, Angers University, Angers, France.

Received: 12 March 2021 Accepted: 8 September 2021

Published online: 26 September 2021

\section{References}

1. Schmidt M, Hajage D, Demoule A, Pham T, Combes A, Dres M, et al. Clinical characteristics and day-90 outcomes of 4244 critically ill adults with COVID19: a prospective cohort study. Intensive Care Med. 2021;47(1):60-73.

2. Frat JP, Thille AW, Mercat A, Girault C, Ragot S, Perbet $S$, Prat G, Boulain T, Morawiec E, Cottereau A, Devaquet J, Nseir S, Razazi K, Mira JP, Argaud L, Chakarian JC, Ricard JD, Wittebole X, Chevalier S, Herbland A, Fartoukh M, Constantin JM, Tonnelier JM, Pierrot M, Mathonnet A, Béduneau G, Delétage-Métreau C, Richard JCM, Brochard L, Robert R. High-flow oxygen through nasal cannula in acute hypoxemic respiratory failure. N Engl I Med. 2015;372(23):2185-96.

3. Rochwerg B, Granton D, Wang DX, Helviz Y, Einav S, Frat JP, et al. High flow nasal cannula compared with conventional oxygen therapy for acute hypoxemic respiratory failure: a systematic review and meta-analysis. Intensive Care Med. 2019;45(5):563-72.

4. Expert recommendations on the intensive care of patients infected with SARS-COV2 Version 5 of 07/11/2020 SRLF-SFAR-GFRUP-SPILF-SPLF-SFMU. https://sfar.org/download/recommandations-dexperts-portant-sur-la-priseen-charge-en-reanimation-des-patients-en-periode-depidemie-a-sars-cov2/ ; 2020. Accessed 25 Dec 2020.

5. Séverin A, Ozguler A, Baer G, Baer M, Loeb T. Use of high-flow nasal cannula in out-of-hospital setting[published online ahead of print, 2021 Apr 5]. Am J Emerg Med. 2021;S0735-6757(21):00293-X. https://doi.org/10.1016/j.ajem.2 021.04.008.

6. Roca O, Messika J, Caralt B, Garcia de Acilu M, Sztrymf B, Ricard JD, et al. Predicting success of high-flow nasal cannula in pneumonia patients with hypoxemic respiratory failure: The utility of the ROX index. J Crit Care. 2016; 35:200-5.

7. Gaeckle N, Lee J, Park Y, Kreykes G, Evans M, Hogan Jr C. Aerosol generation from the respiratory tract with various modes of oxygen delivery. Am J Respir Crit Care Med. 2020;202(8):1115-24.

8. Hui DS, Chow BK, Lo T, Tsang OTY, Ko FW, Ng SS, et al. Exhaled air dispersion during high-flow nasal cannula therapy versus CPAP via different masks. Eur Respir J. 2019;53:1802339.

9. Ip M, Tang JW, Hui DS, Wong AL, Chan MT, Joynt GM et al. Airflow and droplet spreading around oxygen masks: a simulation model for infection control research. Am J Infect Control. 2007;35:684-9.

\section{Publisher's Note}

Springer Nature remains neutral with regard to jurisdictional claims in published maps and institutional affiliations.

Ready to submit your research? Choose BMC and benefit from:

- fast, convenient online submission

- thorough peer review by experienced researchers in your field

- rapid publication on acceptance

- support for research data, including large and complex data types

- gold Open Access which fosters wider collaboration and increased citations

- maximum visibility for your research: over $100 \mathrm{M}$ website views per year

At BMC, research is always in progress.

Learn more biomedcentral.com/submissions 